\title{
Influence of Biomass Pyrolysis Temperature, Heating Rate and Type of Biomass on Produced Char in a Fluidized Bed Reactor
}

\author{
Toshiyuki Iwasaki ${ }^{1}$, Seiichi Suzuki ${ }^{1} \&$ Toshinori Kojima ${ }^{1}$ \\ ${ }^{1}$ Department of Materials and Life Science, Faculty of Science and Technology, Seikei University, Japan \\ Correspondence: Toshinori Kojima, Department of Materials and Life Science, Faculty of Science and \\ Technology, Seikei University, 3-1 Kichijoji-kitamachi 3-chome, Musashino-shi, Tokyo 180-8633, Japan. Tel: \\ 81-42-237-3750. E-mail: kojima@st.seikei.ac.jp
}

Received: November 28, 2013 Accepted: February 15, 2014 Online Published: April 29, 2014

doi:10.5539/eer.v4n2p64

URL: http://dx.doi.org/10.5539/eer.v4n2p64

\begin{abstract}
Biomass pyrolysis experiments were carried out in a fluidized bed reactor (FBR) and produced char yields were measured for 3 kinds of softwoods, 3 kinds of hardwoods, 2 kinds of herbaceous plants and 3 kinds of agricultural residues. Pyrolysis temperature range was between $300{ }^{\circ} \mathrm{C}$ and $1200{ }^{\circ} \mathrm{C}$, and heating rate was fast $\left(100-1000{ }^{\circ} \mathrm{C} / \mathrm{s}\right)$ or slow $\left(10^{\circ} \mathrm{C} / \mathrm{min}\right)$. After the pyrolysis, produced char was collected with bed particles and only the char was separated from bed particles by sieving. Surface of the produced char was observed by SEM to confirm bed particles adhesion behavior on the surface of char. Char-bed particles (alumina particles) adhesion were observed mainly under fast pyrolysis condition for most of the biomass samples. Char yields by fast pyrolysis were much lower than those by slow pyrolysis of Eucalyptus camaldulensis (hardwood), Japanese cypress (softwood), Switchgrass (herbaceous plant) and Bagasse (agricultural residue), respectively. In the case of fast pyrolysis condition, char yields from softwood species were lower than those from other biomass species.
\end{abstract}

Keywords: biomass, pyrolysis, fluidized bed, char, agglomerate

\section{Introduction}

Biomass energy, the alternative carbonaceous fuel to fossil fuel is carbon-neutral and it does not increase $\mathrm{CO}_{2}$ as other renewable energies. Integrated gasification power generation system attracts attention because of its potentially high energy conversion efficiency as one of the biomass energy conversion systems to electricity. Biomass pyrolysis is the first step of the biomass gasification process to produce gas, tar, and char under inert gas atmosphere. Product composition and yield of the biomass pyrolysis would depend on pyrolysis temperature, heating rate (Dall'Ora et al., 2008; Keown et al., 2005; Williams \& Besler, 1996), holding time (Wannapeera et al., 2011) and the properties of raw biomass such as shape, size (Asadullah et al., 2009), and type of biomass (Antal et al., 2000; Demirbas, 2004; Wei et al., 2006; Zanzi et al., 2006). The product composition in turn would affect the energy conversion efficiency. Since the gasification rate of char is slowest among the pyrolysis products (Dall'Ora et al., 2008; Asadullah et al., 2009), char conversion characteristics is one of the most important factors to determine the energy conversion efficiency from biomass.

Fluidized bed reactors (FBR) are appropriate for pyrolysis, gasification and combustion of woody biomass due to its high efficiency of heat transfer. In spite of this advantage, FBR has own agglomeration problem. Many investigators have reported this agglomeration problem as follows. In the case of biomass gasification and combustion, alkali and alkaline earth metallic (AAEM) species in biomass ash melts and they stick to bed particles such as silica sand between 700 and $900{ }^{\circ} \mathrm{C}$ (Chaivatamaset et al., 2011; Chirone et al., 2006; Scala et al., 2003). In the case of biomass pyrolysis, Burton et al. (2012) reported organic species which is released during pyrolysis from mallee leaf may cause to char-sand agglomeration. Namioka et al. (2004) reported that tar from woody biomass (cedar) pyrolysis in circulating fluidized bed gasifier (CFBG) process with silica sand as bed particles at $873 \mathrm{~K}$ caused defluidization and called this phenomenon "bogging" effect. Wild et al. (2012) carried out pyrolysis experiment of the wheat straw-derived organosolv lignin in a bubbling fluidized bed with sand bed at $500{ }^{\circ} \mathrm{C}$ and reported that the effect was caused by char-sand agglomerates. Thus, it is necessary to know the own problems such as agglomeration or adhesion, in order to improve the FBR design for industrial biomass conversion process.

In this series of studies, biomass pyrolysis experiments in FBR were carried out under various conditions 
including heating rate, pyrolysis temperatures and type of biomass. In this paper, the results on char yield (Iwasaki \& Kojima, 2013) and adhesion behavior (Iwasaki et al., 2012, 2013) are briefly summarized and future task is commented.

\section{Method}

\subsection{Biomass Samples}

As biomass samples, Japanese cedar (Cryptomeria japonica), Japanese cypress (Chamaecyparis obtusa), and Japanese pine (Pinus japonica) were used as softwood, Japanese zelkova (Zelkova serrata), Red mangrove (Rhizophora mucronata), and River red gum (Eucalyptus camaldulensis) as hardwood, Switchgrass (Panicum virgatum) and Miscanthus (Ophiopogon malayanus) as herbaceous plant and Bagasse, Empty Fruit Bunches (EFB) and Rice husk were used in this study. Their proximate analyses from JIS M8814 method are shown in Table 1. The raw biomass sample was crushed with wonderblender (Osaka Chemical Co., Ltd.) and sieved, and the particles, the diameter of which was between $1.4 \mathrm{~mm}$ and $2.0 \mathrm{~mm}$, were used for the experiments (only for Rice husk sample were used as they are).

Table 1. Property of biomass samples

\begin{tabular}{llccc}
\hline \multirow{2}{*}{ Group } & \multirow{2}{*}{ Biomass species } & \multicolumn{3}{c}{ Proximate analysis (wt \%) } \\
\cline { 3 - 5 } Herbaceous plant & $\mathbf{V M}^{\text {*1 }}$ & Ash & FC $^{\text {*2 }}$ \\
\hline \multirow{3}{*}{ Agricultural residue } & 80.83 & 4.35 & 14.82 \\
& Switchgrass & 80.13 & 2.69 & 17.18 \\
& Miscanthus & 79.76 & 4.57 & 15.67 \\
& Bagasse & 76.47 & 3.16 & 20.37 \\
& Empty Fruit Bunches (EFB) & 64.80 & 19.39 & 15.81 \\
\cline { 2 - 4 } Softwood & Rice husk & 82.18 & 0.57 & 17.25 \\
& Japanese pine & 84.75 & 0.17 & 15.08 \\
& Japanese cypress & 83.39 & 0.20 & 16.41 \\
\hline \multirow{3}{*}{ Hardwood } & Japanese cedar & 79.70 & 1.12 & 19.18 \\
& Japanese zelkova & 81.16 & 0.89 & 17.95 \\
& Rhizophora mucronata & 78.92 & 2.58 & 18.50 \\
\hline
\end{tabular}

\subsection{Pyrolysis Experiments}

Schematic diagram of experimental setup is shown Figure 1. A reactor tube made of alumina with the inner diameter of $35 \mathrm{~mm}$ and the height of $600 \mathrm{~mm}$, was used as a FBR. Alumina particles (mean diameter : $215 \mu \mathrm{m}$ ) were fluidized with nitrogen gas at $6 U_{\mathrm{mf}}$ (six times of minimum fluidization velocity of bed material) $[\mathrm{m} / \mathrm{s}]$. The bed with the distributor was made of alumina and heated by siliconit ${ }^{\circledR}$ electric heaters. The temperature in the bed was measured with a thermocouple ("TC" in Figure 1) and controlled by a programmable temperature record controller ("TRC" in Figure 1). Pyrolysis temperature range was between $300{ }^{\circ} \mathrm{C}$ and $1200{ }^{\circ} \mathrm{C}$. FBR was used for both fast pyrolysis and slow pyrolysis.

In fast pyrolysis ( $\lesssim 1000{ }^{\circ} \mathrm{C} / \mathrm{s}$ ), an about $1000 \mathrm{mg}$ biomass sample was divided into about $100 \mathrm{mg}$ samples and intermittently supplied. After all samples were supplied completely, they were kept for ten minutes at the pyrolysis temperature. In slow pyrolysis $\left(10^{\circ} \mathrm{C} / \mathrm{min}\right)$, sample biomass was supplied at the room temperature under the nitrogen flow and then the temperature was heated to the pyrolysis temperature at the rate of $10^{\circ} \mathrm{C} / \mathrm{min}$. Under the both of the conditions, after the sample biomass was pyrolyzed, reactor was cooled down in the nitrogen flow and then char with alumina bed particles were collected. Only the char larger than $710 \mu \mathrm{m}$ was separated from alumina particles about $215 \mu \mathrm{m}$ with a sieve of $710 \mu \mathrm{m}$ opening. And then, surface of the produced char was observed by scanning electron microscopy (SEM) using a JSM-5200 (JEOL Japan) to confirm bed particles adhesion behavior on the surface of char. 


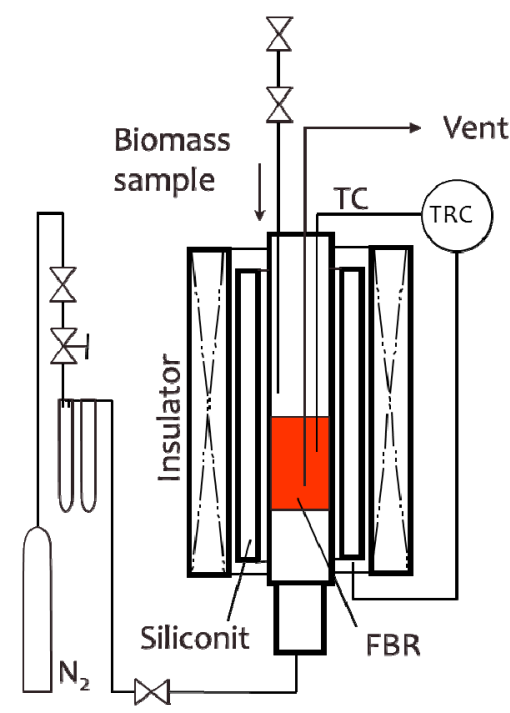

Figure 1. Schematic diagram of experimental

\subsection{Estimate of Char Yields}

Char yield was calculated from its weight, however alumina bed particles adhered on the surface of obtained char, leading to increase its weight, thus "Apparent char yield" was calculated as follows

$$
(\text { Apparent char yield })[w t \%]=\frac{\text { Recovered char weight }[w t g]}{\text { Supplied biomass weight }[w t g]}
$$

To obtain the adhesion alumina bed particles on surface of char, obtained char samples were burned to residuals in an electric furnace at $815^{\circ} \mathrm{C}$ and residuals were weighed. Then "Adhesion bed particles rate" was calculated with Equation (2) assuming all ash remained in char via FBR.

$$
\text { ( Adhesion bed particles rate) }[w t \%]=(\text { Re sidual yield }) \text { [wt\%] - ( Ash yield from JIS }) \text { [wt\%] }
$$

where "Residual yield" is recovered rate after combustion of char with bed particles on the basis of supplied biomass, and "Ash yield from JIS" is "Ash" in Table 1.

The intrinsic char yield without adhesion alumina bed particles was calculated with Equation (3).

$$
(\text { Intirinsic char yield })[w t \%]=(\text { Apparentchar yield })[w t \%]-(\text { Adhesion bed particles rate })[w t \%]
$$

Then "Intrinsic char yield on the basis of dry ash free (Intrinsic char yield [wt $\%$ daf])" was calculated with Equation (4) in order to eliminate the effect of elements release from ash at high temperature.

$$
\text { (Intirinsic char yield ) }[w t \% d a f]=\frac{(\text { Intirinsic char yield })[w t \%]-(\text { Ash yield from JIS })[w t \%]}{\{100-(\text { Ash yield from JIS })[w t \%]\}} \times 100
$$

\section{Results and Discussion}

\subsection{Char-Bed Particles Adhesion}

Figure 2 shows SEM picture (50 times magnification) of char surface produced by difference temperature and heating rate from 4 biomass samples. When char-bed particles adhesion is observed, spherical and white materials are found to be placed on the surface of the char as shown in the SEM image. Under the slow $\left(10{ }^{\circ} \mathrm{C} / \mathrm{min}\right)$ pyrolysis condition, char-bed particles adhesion was not observed for char from Japanese cypress, Eucalyptus camaldulensis and Bagasse samples, except for char from Switchgrass sample which showed. It was observed between 400 and $800{ }^{\circ} \mathrm{C}$. Under the fast pyrolysis, Eucalyptus camaldulensis sample showed the char-bed particles adhesion around $800^{\circ} \mathrm{C}$, Japanese cypress, between 600 and $1200{ }^{\circ} \mathrm{C}$, Bagasse, between 800 and $1000{ }^{\circ} \mathrm{C}$ and Switchgrass, between 300 and $1000^{\circ} \mathrm{C}$. Figure 3 shows adhesion bed particles rate during fast and slow pyrolysis conditions. In the case of Japanese cypress during fast pyrolysis at $800{ }^{\circ} \mathrm{C}$, adhesion bed particles rate reached to the maximum and the value was much higher than those of the other species. The char-bed particles adhesion was observed mainly under fast pyrolysis condition. 


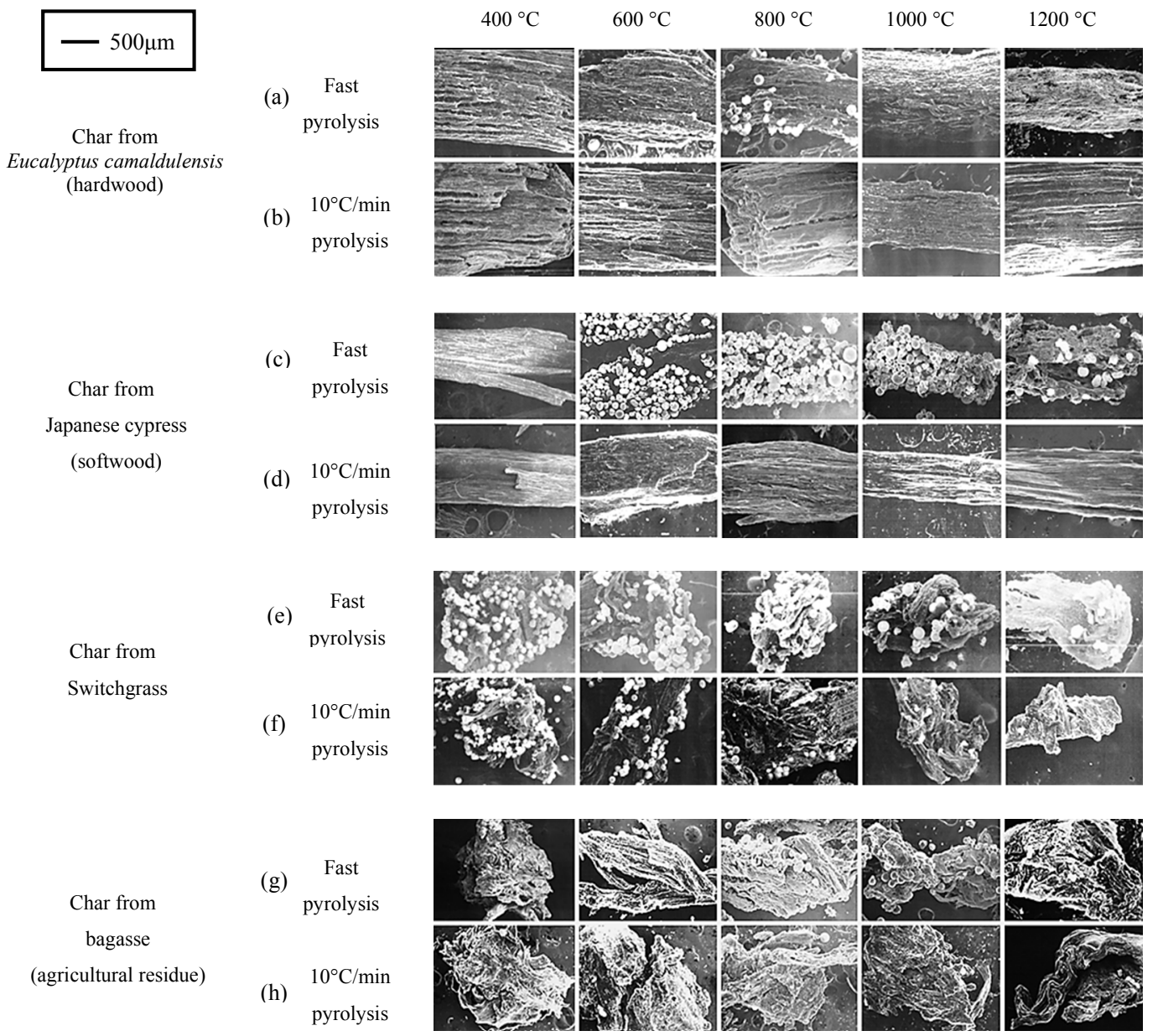

Figure 2. SEM pictures of char surface produced by fast and slow pyrolysis from various biomass samples (Iwasaki et al., 2013)

Figure 4 shows adhesion bed particles rate during fast pyrolysis condition for other biomass samples. Three kinds of hardwood (Japanese zelkova, Red mangrove and Eucalyptus camaldulensis) showed the char-bed particles adhesion between 700 and $900{ }^{\circ} \mathrm{C}$, three kinds of softwood (Japanese cedar, Japanese cypress and Japanese pine), between 600 and $1200{ }^{\circ} \mathrm{C}$. Similar trend of adhesion was observed for the other samples of hardwood and softwood groups. But influence of temperature on char-bed particles adhesion was not similar for herbaceous plant and agricultural residue groups. Miscanthus showed the char-bed particles adhesion between 700 and $900{ }^{\circ} \mathrm{C}$ and EFB, between 400 and $900{ }^{\circ} \mathrm{C}$. For rice husk, adhesion phenomenon was not observed on the surface of char but it was observed inside the rice husk char between 500 and $1000{ }^{\circ} \mathrm{C}$ (Iwasaki et al., 2013). However, drastic increase of char-bed particles adhesion was observed at the char surface at $1200^{\circ} \mathrm{C}$.

In general, adhesion phenomena such as char-bed and/or bed agglomeration are observed at higher than $700{ }^{\circ} \mathrm{C}$ in FBR for biomass gasification or combustion because biomass ash melts at high temperature and sticks to bed particles such as silica sand (Chaivatamaset et al., 2011; Chirone et al., 2006; Scala et al., 2003). While the drastic increase of char-bed particles adhesion observed at $1200{ }^{\circ} \mathrm{C}$ is explained by this mechanism, the other adhesion phenomena are difficult to be explained. The Burton et al. (2012) carried out mallee leaf pyrolysis experiments between 300 and $700{ }^{\circ} \mathrm{C}$ and they reported char-sand agglomeration. And then, they found reduction in agglomeration yield due to solvent of chloroform and methanol (ratio: 4:1) washing, measured yield of solvent-soluble organic matter and so on to confirm the char-sand agglomeration was caused by organic species. Char-bed particles adhesion between 300 and $400{ }^{\circ} \mathrm{C}$ was also observed in this study. And it was not observed above $1000{ }^{\circ} \mathrm{C}$ for various samples expect rice husk. Thus, effects of heating rate, temperature and type of biomass on char-bed adhesion were investigated and it was concluded that char-bed particles adhesion was caused by organic species such as tar expect rice husk. 
The cause of difference in the char-bed particles adhesion rate between fast and slow heating rate conditions will be discussed later.

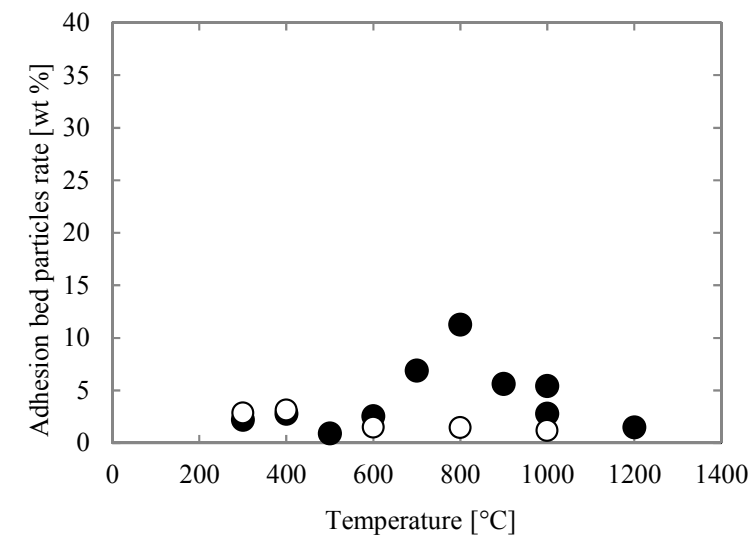

(a) Eucalyptus camaldulensis

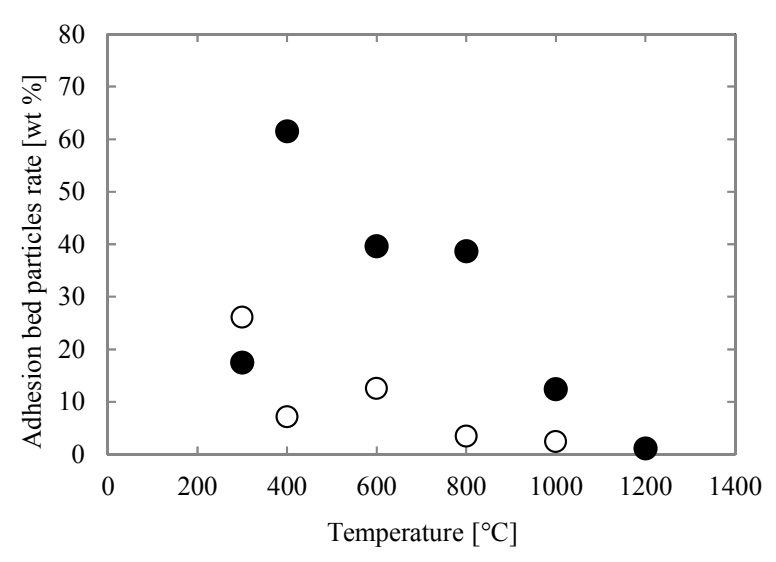

(c) Switchgrass

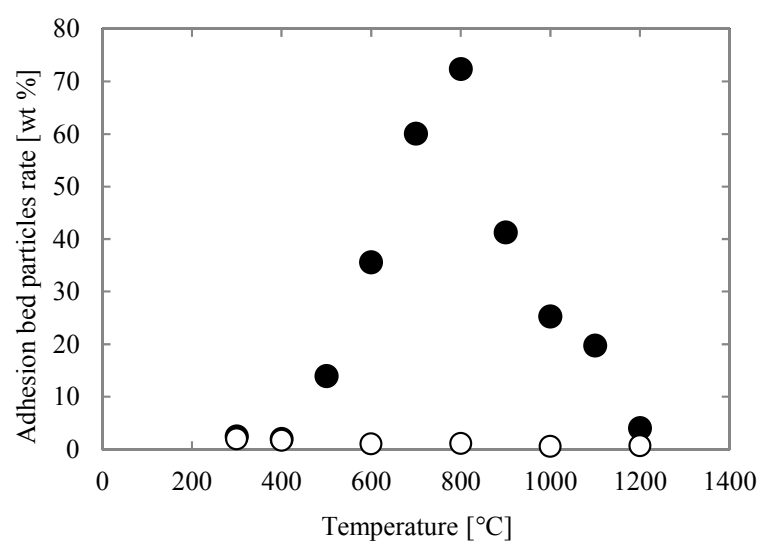

(b) Japanese cypress

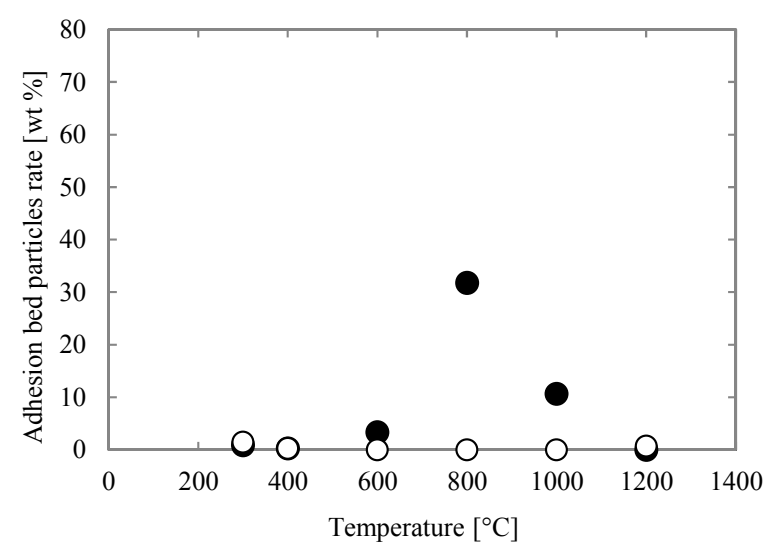

(d) Bagasse

\section{Fast pyrolysis $\bigcirc 10^{\circ} \mathrm{C} / \mathrm{min}$}

Figure 3. Effect of pyrolysis temperature, heating rate and biomass species on adhesion bed particles rate (mainly from Iwasaki et al., 2013) 


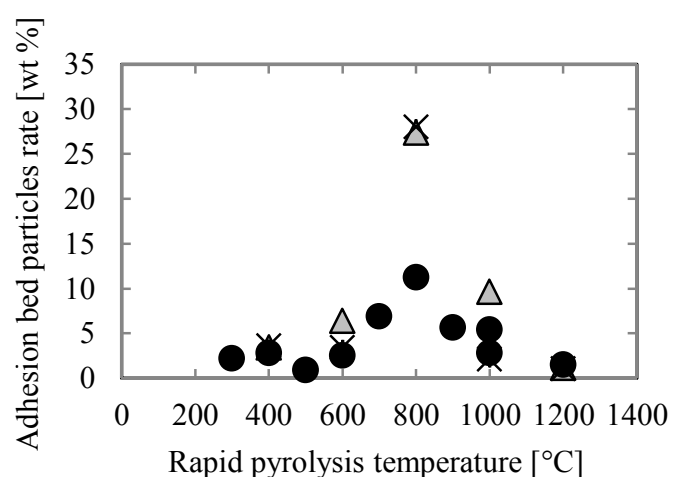

$\triangle$ Rhizophoramucronata $\times$ Japanese zelkova

- Eucalyptus camaldulensis

(a) hardwood

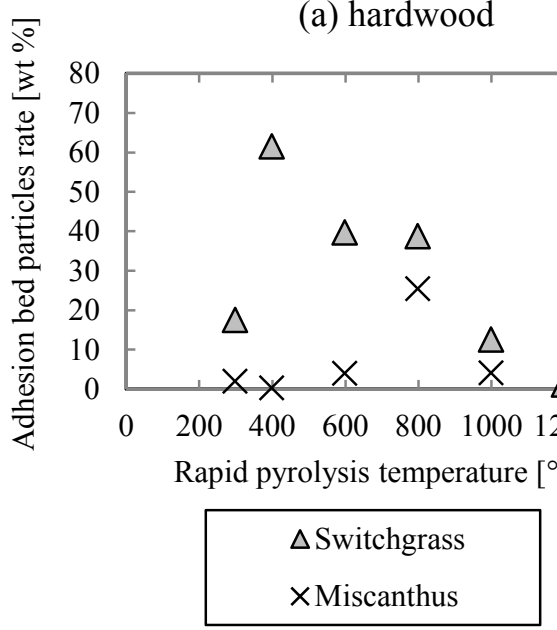

(c) Herbaceous plant

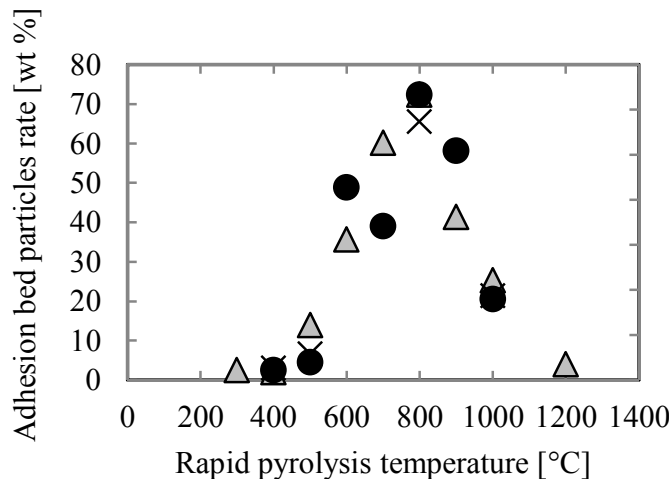

$\triangle$ Japanese cypress
$\times$ Japanese cedar
OJapanese pine

(b) softwood

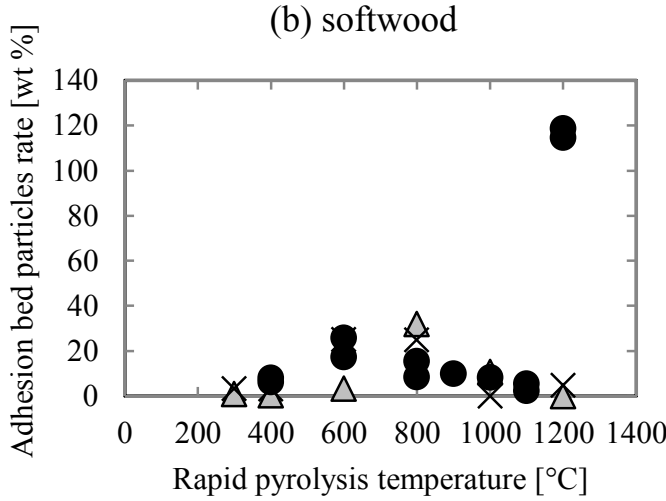

$\Delta$ Bagasse

$\times$ Empty Fruit Bunches

- Rice husk

(d) Agricultural residue

Figure 4. Effect of pyrolysis temperature and biomass species on adhesion bed particles rate during fast pyrolysis (mainly from Iwasaki et al., 2013)
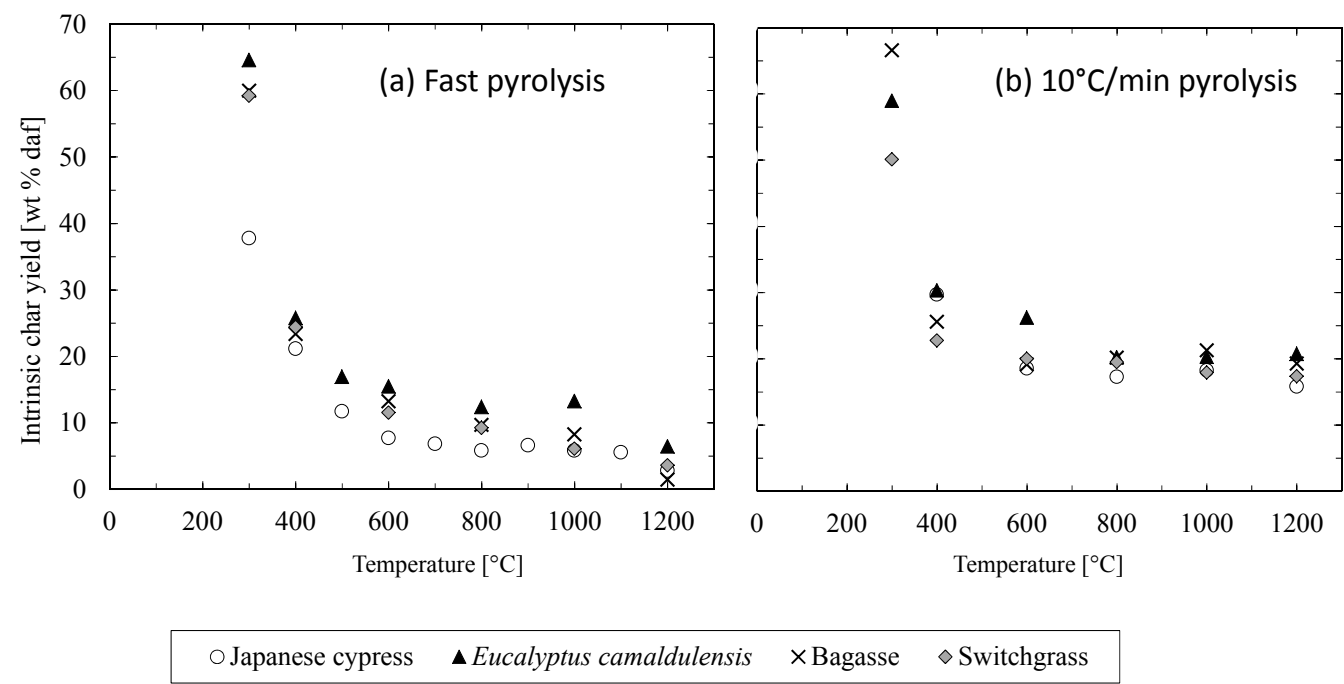

Figure 5. Effect of pyrolysis temperature, heating rate and type of biomass on char yield. (Iwasaki \& Kojima, 2013) 


\subsection{Char Yields}

Figure 5 shows intrinsic char yields [wt\% daf] (hereinafter call "char yield") from 4 samples at difference heating rate and temperature. Char yields for both heating rates decreased drastically between 300 and $600{ }^{\circ} \mathrm{C}$. And then char yield was kept unchanged between 600 and $1200{ }^{\circ} \mathrm{C}$ for slow pyrolysis. In the case of fast pyrolysis, char yield was hardly changed or slightly decreased between 600 and $1000^{\circ} \mathrm{C}$. Clearly decrease was observed between 1000 and $1200{ }^{\circ} \mathrm{C}$. At temperatures above $1000{ }^{\circ} \mathrm{C}$ in fast pyrolysis, black particles like the soot were observed in the volatile gas at the section of "Vent" in Figure 1. Zhang et al. (2006) pyrolyzed Hinoki cypress sawdust in a drop-tube furnace (DTF). Coke (or soot) yield increased and char yield decreased between 1000 and $1100{ }^{\circ} \mathrm{C}$. Its result agrees well with this study.

Char yield for fast pyrolysis is lower than that for slow pyrolysis in Figures 5(a) and (b). The trend of effect of heating rate on char yield is reported in many literatures (Dall'Ora et al., 2008; Keown et al., 2005; Williams \& Besler, 1996; Zanzi et al., 1996). Keown et al. (2005) explained that because recombination reactions less occur inside a particle under fast heating conditions and, in the course of reactions between volatiles and char, the "self-gasification" of nascent char by reactive components in the volatiles is favored at fast heating rate mode. Chaiwat et al. (2009) reported that cross-linking reaction from cellulose affected char yield and structure change during pyrolysis at different heating rates. Under the fast heating rate, char yield from Japanese cypress was lower than char yield from other samples in Figure 5(a). Figure 6 shows effect of type of biomass and pyrolysis temperature on char yield under the fast pyrolysis condition. In general similar trend of char yields is observed in the case of fast pyrolysis as above for all species. While the absolute values of char yield are almost same for all species within one group for hardwood (Figure 6(a)), softwood (Figure 6(b)) and herbaceous plant (Figure 6(c)) groups, EFB sample showed trend of higher char yield than other samples with in agricultural residue group (Figure 6(d)). Wei et al. (2006) indicated char yield from agricultural residues higher than woody biomass. Demirbas (2004) reported 3 kinds of agricultural residue samples with high lignin content from gave high char yield. Antal et al. (2000) reported relationship of lignin content and fixed carbon from 19 kinds of softwoods, hardwoods and agricultural residues samples and that samples with high lignin contents mainly indicated high fixed carbon yield. But difference of hardwood and softwood was not clearly mentioned. In general, softwood samples have higher lignin content than hardwood samples (Hasegawa et al., 2005). Blasi (2009) reported the differences between wood species belonging to the standard hardwood or softwood categories are relatively small. But char yields from softwood species are lower than those from other biomass species in Figures 6(a) and (b). Dall'Ora et al. (2008) produced chars from pine (softwood) and beech wood (hardwood) by fast pyrolysis in an entrained flow reactor and by slow pyrolysis in a thermogravimetric analyzer. For slow pyrolysis, char yield from softwood showed $2 \%$ daf higher than hardwood at 1273 and $1573 \mathrm{~K}$. For fast pyrolysis, char yield from softwood showed $4-5 \%$ daf lower than hardwood at the same temperature. Thus, it is suggested that the char yield is not only affected by the lignin content but also other factors such as heating rate: rather the reverse order of char yield was observed by the different heating rate.

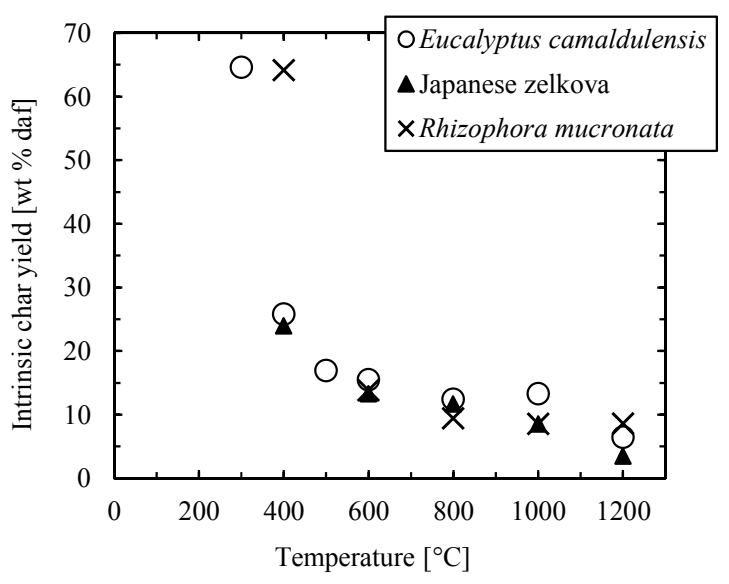

(a) Hardwood

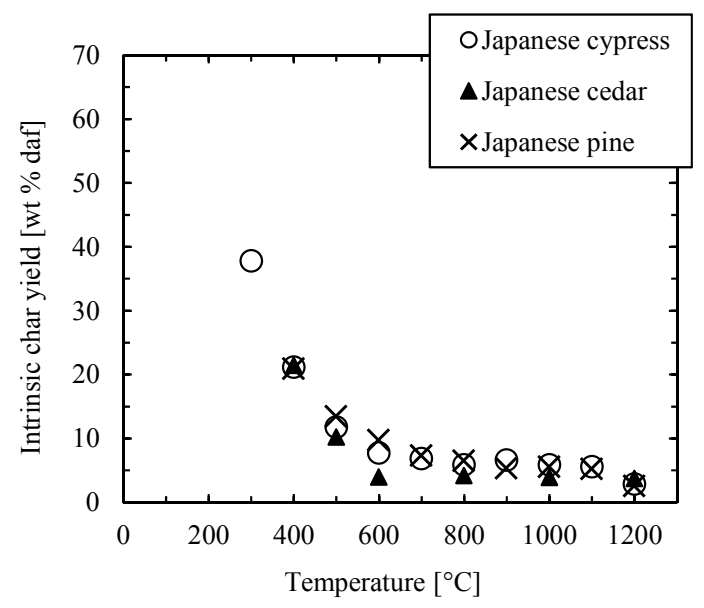

(b) Softwood 


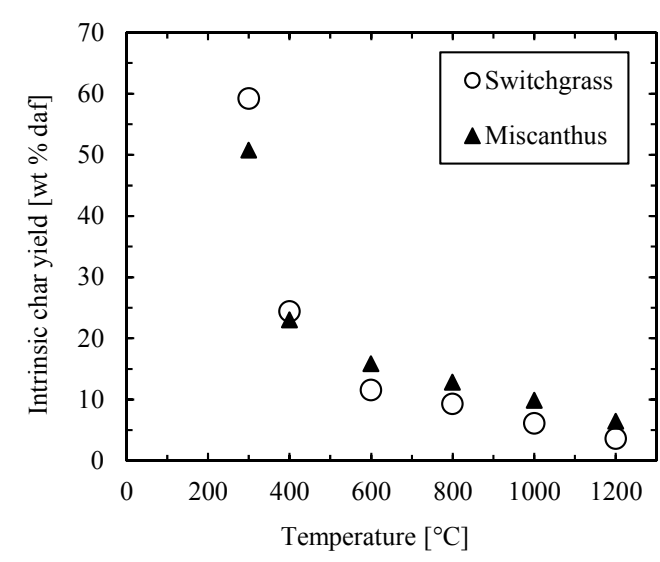

(c) Herbaceous plant

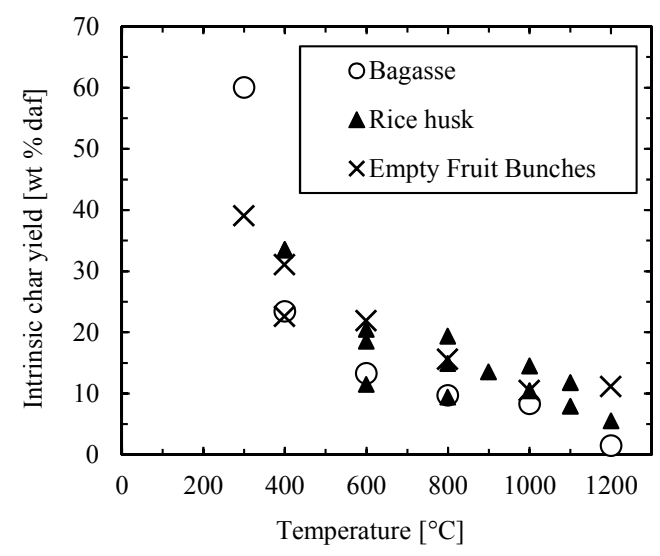

(d) Agricultural residue

Figure 6. Effect of pyrolysis temperature and type of biomass on char yield under the fast pyrolysis condition.

(Iwasaki \& Kojima, 2014)

\subsection{Relation Between Char Yields and Char-Bed Particles Adhesion Rate}

In the section of 3.1, we reported that the char-bed particles adhesion mainly found under the fast heating rate condition. The results are reasonably explained by the difference in char yield shown in Figure 5. The smaller value of char yield means more amount of volatile. Considering that the organic materials are suggested to cause the adhesion phenomena, the present results in Figure 5 explain the difference of adhesion rate between fast and slow heating in Figure 4. The more adhesion rate of soft wood is also explained by the difference in char yield between species shown in Figure 6 .

\section{Conclusion}

Biomass pyrolysis experiments were carried out in a fluidized bed reactor (FBR). Produced char yields were measured and char-adhesion was observed for various biomass species. Char-bed particles adhesion was observed mainly within fast pyrolysis condition expect the switch grass sample. The mount of adhesion and its temperature range strongly depended on the biomass types. Char yields for fast pyrolysis were lower than for slow pyrolysis. Under the fast pyrolysis condition, char yield from softwood species was lower than that from other biomass species. Influence of temperature, heating rate and type of biomass on char yield was reported.

\section{References}

Antal, M. J. Jr., Allen, S. G., Dai, X., Shimizu, B., Tam, M. S., \& Grønli, M. (2000). Attainment of the Theoretical Yield of Carbon from Biomass. Industrial \& Engineering Chemistry Research, 39, 4024-4031. http://dx.doi.org/10.1021/ie000511u

Asadullah, M., Zhang, S., Min, Z., Yimsiri, P., \& Li, C. Z. (2009). Importance of Biomass Particle Size in Structural Evolution and Reactivity of Char in Steam Gasification. Industrial \& Engineering Chemistry Research, 48, 9858-9863. http://dx.doi.org/10.1021/ie901214z

Blasi, C. D. (2009). Combustion and gasification rates of lignocellulosic chars. Progress in Energy and Combustion Science, 35, 121-140. http://dx.doi.org/10.1016/j.pecs.2008.08.001

Burton, A., \& Wu, H. (2012). Mechanistic Investigation into Bed Agglomeration during Biomass Fast Pyrolysis in a Fluidized-Bed Reactor. Energy \& Fuels, 26(11), 6979-6987.

Chaivatamaset, P., Sricharoon, P., \& Tia, S. (2011). Bed agglomeration characteristics of palm shell and corncob combustion in fluidized bed. Applied Thermal Engineering, 31, 2916-2927. http://dx.doi.org/10.1016/j.applthermaleng.2011.05.021

Chaiwat, W., Hasegawa, I., Tani, T., Sunagawa, K., \& Mae, K. (2009). Analysis of Cross-Linking Behavior during Pyrolysis of Cellulose for Elucidating Reaction Pathway. Energy \& Fuels, 23, 5765-5772. http://dx.doi.org/10.1021/ef900674b

Chirone, R., Miccio, F., \& Scala, F. (2006). Mechanism and prediction of bed agglomeration during fluidized bed combustion of a biomass fuel: Effect of the reactor scale. Chemical Engineering Journal, 123, 71-80. 
http://dx.doi.org/10.1016/j.cej.2006.07.004

Dall'Ora, M., Jensen, P. A., \& Jensen, A. D. (2008). Suspension Combustion of Wood: Influence of Pyrolysis Conditions on Char Yield, Morphology, and Reactivity. Energy \& Fuels, 22, 2955-2962. http://dx.doi.org/10.1021/ef800136b

Demirbas, A. (2004). Effects of temperature and particle size on bio-char yield from pyrolysis of agricultural residues. Journal of Analytical and Applied Pyrolysis, 72, 243-248. http://dx.doi.org/10.1016/j.jaap.2004.07.003

Hasegawa, I., Fujisawa, H., Sunagawa, K., \& Mae, K. (2005). Quantitative Prediction of Yield and Elemental Composition during Pyrolysis of Wood Biomass (in Japanese). Journal of the Japan Institute of Energy, 84, 46-52. http://dx.doi.org/10.3775/jie.84.46

Iwasaki, T., \& Kojima, T. (2013). Effects of Biomass Species and Pyrolysis Conditions on Char Yield in Fluidized Bed Reactor (in Japanese). Kagaku Kogaku Ronbunshu, 40(1), 65-71. http://dx.doi.org/10.1252/kakoronbunshu.40.65

Iwasaki, T., Satokawa, S., \& Kojima, T. (2013). Adhesion of Fluidized Bed Particles on Biomass Char in Fluidized Bed Rapid Pyrolysis (in Japanese). Journal of the Japan Institute of Energy, 92, $327-336$. http://dx.doi.org/10.3775/jie.92.327

Iwasaki, T., Suganuma, H., Kato, S., Yamasaki, A., Satokawa, S., \& Kojima, T. (2012). Adhesion properties of fluidized bed particles on the surface of char derived from woody biomass samples in rapid pyrolysis. Chemistry Letters, 41, 1544-1546. http://dx.doi.org/10.1246/cl.2012.1544

Keown, D. M., Favas, G., Hayashi, J., \& Li, C. -Z. (2005). Volatilisation of alkali and alkaline earth metallic species during the pyrolysis of biomass: differences between sugar cane bagasse and cane trash. Bioresource Technology, 96, 1570-1577. http://dx.doi.org/10.1016/j.biortech.2004.12.014

Namioka, T., Yoshikawa, K., Hatano, H., \& Suzuki, Y. (2004). Gasification and Tar Emission Abatement Performances of Activated Alumina in a Circulating Fluidized Bed: Tar Emission Abatement Technology with Activated Alumina (in Japanese). Kagaku Kogaku Ronbunshu, 30(6), 762-770. http://dx.doi.org/10.1252/kakoronbunshu.30.762

Scala, F., Chirone, R., \& Salatino, P. (2003). The influence of fine char particles burnout on bed agglomeration during the fluidized bed combustion of a biomass fuel. Fuel Processing Technology, 84, $229-241$. http://dx.doi.org/10.1016/S0378-3820(03)00108-5

Wannapeera, J., Fungtammasan, B., \& Worasuwannarak, N. (2011). Effects of temperature and holding time during torrefaction on the pyrolysis behaviors of woody biomass. Journal of Analytical and Applied Pyrolysis, 92, 99-105. http://dx.doi.org/10.1016/j.jaap.2011.04.010

Wei, L., Xu, S., Zhang, L., Zhang, H., Liu, C., Zhu, H., \& Liu, S. (2006). Characteristics of fast pyrolysis of biomass in a free fall reactor. Fuel Processing Technology, 87, 863-871. http://dx.doi.org/10.1016/j.fuproc.2006.06.002

Wild, P. J., Huijgen, W. J. J., \& Heeres, H. J. (2012). Pyrolysis of wheat straw-derived organosolv lignin. Journal of Analytical and Applied Pyrolysis, 93, 95-103. http://dx.doi.org/10.1016/j.jaap.2011.10.002

Williams, P. T., \& Besler, S. (1996). The influence of temperature and heating rate on the slow pyrolysis of biomass. Renewable Energy, 7, 233-250. http://dx.doi.org/10.1016/0960-1481(96)00006-7

Zanzi, R., Sjöström, K., \& Björnbom, E. (1996). Rapid high-temperature pyrolysis of biomass in a free-fall reactor. Fuel, 75, 545-550. http://dx.doi.org/10.1016/0016-2361(95)00304-5

Zhang, Y., Kajitani, S., Ashizawa, M., \& Miura, K. (2006). Peculiarities of Rapid Pyrolysis of Biomass Covering Medium-and High-Temperature Ranges. Energy \& Fuels, 20, 2705-2712. http://dx.doi.org/10.1021/ef060168r

\section{Copyrights}

Copyright for this article is retained by the author(s), with first publication rights granted to the journal.

This is an open-access article distributed under the terms and conditions of the Creative Commons Attribution license (http://creativecommons.org/licenses/by/3.0/). 